\title{
The potential future roles of natural compounds and microbial bioherbicides in weed management in crops
}

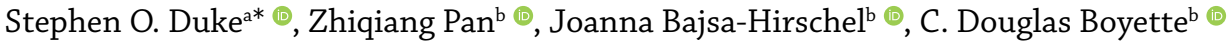

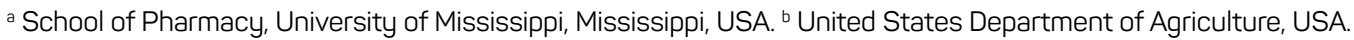

\begin{abstract}
There is a popular demand for more natural means of pest management, including weed management, as well as a demand by farmers for herbicides with new chemistries and/or new modes of action to which current weed resistances do not apply. Natural compounds offer a source compounds that can either meet these needs in their natural state or as templates for herbicides with better physicochemical properties for field use. In some cases, simply identifying a good herbicide target site with a natural phytotoxin can be valuable, even though that compound is not used as a template for new herbicides. Compared to insecticides and fungicides, natural compounds have been under-utilized for herbicides. Despite their
\end{abstract}

Keywords: Herbicide; microbial bioherbicide; mode of action; mycoherbicide; natural phytotoxin

Journal Information: ISSN - 2675-9462

Website: http://awsjournal.org

Journal of the Brazilian Weed Science Society

How to cite: Duke SO, Pan

Z, Bajsa-Hirschel J, Boyette

$\mathrm{CD}$. The potential future roles

of natural compounds and

microbial bioherbicides in weed

management in crops. Adv Weed Sci.

2022;40(Spec1):e020210054.

hitps//ddoiorg/10.51694/AdWWeedSd/2022;40:seventy-five003

Approved by:

Editor in Chief: Carlos Eduardo

Schaedler

Associate Editor: Per Kudsk

Conflict of Interest: The authors declare that there is no conflict of interest regarding the publication of this manuscript.

Received: June 24, 2021

Approved: October 8, 2021

* Corresponding author: <sduke@olemiss.edu>

\section{(c) (1)}

This is an open-access article distributed under the terms of the

Creative Commons Attribution License, which permits unrestricted use, distribution, and reproduction in any medium, provided that the original author and source are credited.

Copyright: 2021

\section{Introduction}

Agriculture in developed countries has primarily relied on synthetic herbicides for weed management for more than 70 years. This technology is showing its age with the ever growing evolution of resistance to available commercial herbicides and even resistance by non-target site mechanisms of resistance to herbicides yet to be introduced (Gaines et al., 2020). The number of herbicides being introduced with new molecular targets and/or new chemical classes for which no resistance exists is few (Qu et al., 2021). Natural products have been the inspiration for insecticides and fungicides with new molecular targets, but to a much lesser extent with herbicides (Lorsbach et al., 2019; Sparks, Duke, 2021). This may be partially due to the relatively reduced effort of herbicide discovery after glyphosate dominated the herbicide market, reducing the overall value of that market significantly (Duke, 2012). The fungicide and insecticide markets have not experienced a similar phenomenon. Nevertheless, information on the molecular targets of many natural phytotoxins indicates that natural products could be the basis for new herbicides to help cope with the growing herbicide resistance problem (Dayan, Duke, 2014).

Microbial bioherbicides, as defined by the United States Environmental Protection Agency, are preparations of killed or live microbes to kill weeds. Their utilization carries different problems and risks than those of chemical herbicides. Although there have been significant improvements in the adoption of microbial biofungicides and bioinsecticides in the past 50 years (Marrone, 2019), there have been relatively few advancements in this area with microbial bioherbicides. We briefly discuss these problems and how they might be overcome.

The growing popularity of and political pressure for organic agriculture and food grown without synthetic pesticides is also providing an impetus to discover and develop weed management technologies that can meet these criteria. The demands for such products are not necessarily based on unequivocal information that such organic or more natural farming is more environmentally or toxicologically safe than conventional farming. For example, some studies have shown organic grains to have more mycotoxins than those from conventional farms (e.g., Kuzdraliński et al., 2013). Some mycotoxins (e.g., fumonisins) produced by microbial pathogens that infect crops are orders of magnitude more toxic to humans than most pesticide residues. Nevertheless, there is good reason for intensifying research to provide safe weed management technologies to meet the demands of farmers, consumers, and regulatory bodies though the use of natural phytotoxins and microbial bioherbicides. 
The natural phytotoxin parts of this review have been covered in part by recent papers (e.g., Dayan, Duke, 2014; Lorsbach et al., 2019; Marrone, 2019; Westwood et al., 2018), as have the microbial bioherbicides parts (Cordeau et al., 2016; Harding, Raizada, 2015; Morin, 2020; Watson, 2018; Hasan et al., 2021; Berestetskiy, 2021). This review is meant to discuss the literature on these two topics together, showing how they are related.

\section{Natural Compounds}

\subsection{Used as a herbicide without modification}

Unlike for insecticides and fungicides, few natural compounds are used as found in nature for pest management (Gerwick, Sparks, 2014). Pelargonic acid, a simple fatty acid, has a limited market as a contact herbicide. Its effects are mainly through disruption of the plasma membrane (Dayan, Watson, 2011). It is a contact herbicide used at high application rates. Simple organic acids such as acetic acid are also sold for the organic weed control market (Dayan, Duke, 2010; Duke et al., 2019a). Various plant essential oils such as lemon grass, clove, cinnamon, citrus, and pine oil are sold for weed management (Dayan, Duke, 2010; Duke et al., 2019a). Some of the constituents of these oils are interesting because of their unique modes of action. For example, citral, a monoterpene aldehyde that is a mixture of two isomers and a component of Citrus aurantiifolia oil used for organic weed management (Fagodia et al., 2017) apparently acts by inhibition of single strand DNA-binding proteins (Graña, 2020), a novel mode of action.

However, these products are not as efficacious as commercial, synthetic herbicides, requiring much more of the product for poorer weed management at a much higher cost. For example, Young (2004) found glyphosate to give much better weed control than acetic acid or pine oil sold for weed management and to cost 50- to 80-fold less than these products. Few studies such as this have been done, but commercial farmers, even organic commercial farmers, use very little of these products because of cost and lack of adequate efficacy. For organic farmers, the cost of non-chemical means of weed management (e.g., hoeing) is less than for most of these products. For example, Boyd et al. (2006) found the combined cost of an array of stale seedbed treatments, including labor, for weed management ( $\$$ USD 269/ha) to be much less than weed management with a clove oil product (\$USD 388/ ha). Similarly, Shrestha et al. (2012) found a D-limonenebased herbicide to provide poor weed management and to cost five- to ten-fold more than the use of steam or flame treatments for weed management. Papers abound on the use of exotic essential oils as herbicides (e.g., Hazrati et al., 2017), however, the cost of these essential oils is likely to be even greater than those already on the market as herbicides. Another example is manuka oil, a product of Leptospermnum scoparium, a shrub found in New Zealand.
It is active as a herbicide (Dayan et al., 2011) due to the natural hydroxyphenylpyruvate dioxygenase-inhibiting triketones found therein (Dayan et al., 2007) (see section 2.2), but it is very expensive, even for use in aromatherapy (e.g., \$USD 46.59 for $10 \mathrm{ml}$ for one product on the web in June, 2021). The cost of the weed management with these products would be more than the value of the crop.

The crude botanical product, maize gluten, is sold as a fertilizer, but has weed-controlling properties (Bingamen, Christians, 1995), possibly due to phytotoxic dipeptides (Liu, Christians, 1994). The application rate for weed management is huge (ca. $810 \mathrm{~kg} / \mathrm{ha}$ ).

There are many studies published on formulation methods to improve the efficacy of such products (e.g., Taban etal., 2021), however, there are still no such completely natural commercial products that are competitive with synthetic herbicides. These natural, commercial products are used primarily by home gardeners who want greener pest management with no residual effects and are not concerned by cost.

The plant natural amide compound sarmentine (Figure 1) has been patented and was/is being developed as a herbicide for organic weed management. It is 10 to 30 times more herbicidal than pelargonic acid on grass and dicot weeds (Dayan et al., 2015). These authors found that it has several modes of action, including disruption of the plasma membrane, perhaps by inhibition of enoyl-ACP reductase, and inhibition of photosystem II (PSII) of photosynthesis. Having at least two targets makes the

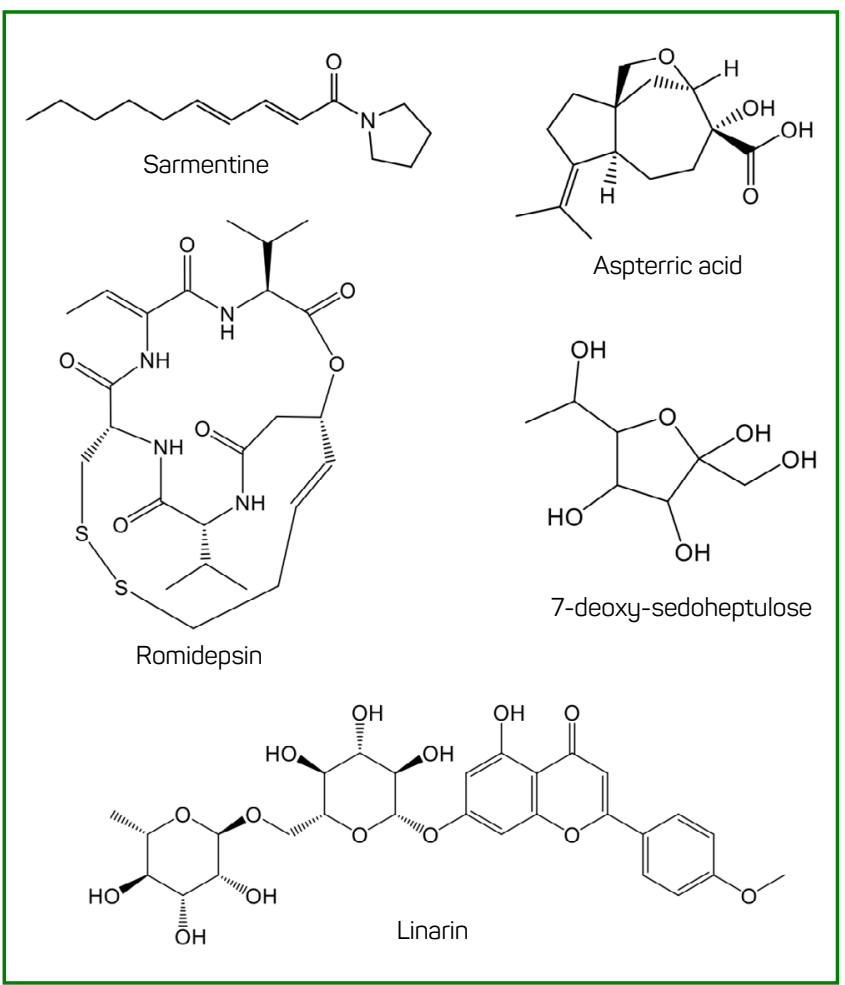

Figure 1 - Structures of some of the natural phytotoxins mentioned in the text. 
evolution of target site resistance more improbable, a trait that no commercial herbicides have (Gressel, 2020).

The tripeptide bialaphos from Streptomyces hygroscopus has been sold in Japan as a fermentation-produced herbicide (Tachibanca, 2003). It must be converted to phosphinothricin in plants to attack its molecular target as a herbicide, glutamine synthetase (GS) (Wild, Ziegler, 1988). The synthesized version of phosphinothricin, glufosinate, is a major herbicide with a growing market, due to the increased utility of glufosinate-resistant crops because of increased in glyphosate-resistant weeds (Duke, 2019a). The commercial product is a racemic mixture of the active, pure L-glufosinate which is identical to phosphinothricin and the inactive D-glufosinate (Copping, Duke, 2007). Efforts are being made to economically produce the L-enantiomer, the use of which would be advantageous to reduce crop injury and for potential toxicological reasons (Takano, Dayan, 2020; Yue et al., 2020). There are numerous other natural GS inhibitors that are not commercialized as herbicides (Lydon, Duke, 1999), perhaps because of high cost and/or inadequate physicochemical properties.

There are many papers on the phytotoxicity of natural compounds that suggest that they have potential as herbicides (e.g., Dayan and Duke, 2014), but, as discussed above, few are likely to ever be used directly as herbicides. The reasons for this are combinations of high costs, poor efficacy, unsuitable physicochemical properties, and/or unacceptable mammalian toxicity. Weed management is the biggest pest problem of many organic farmers, so an effective, economical, and safe natural product herbicide is in great demand, presenting a strong incentive to discover such a natural product that could be used directly as a commercial herbicide.

\subsection{Used as templates for better herbicides}

Simplification of natural compound structure to reduce cost and/or alteration of the structure to improve activity or physicochemical properties (Sparks, Duke, 2021) has been very successful in both commercial pesticide and pharmaceutical development. Compared to insecticides and fungicides, there are relatively few commercial herbicides that can trace their origins back to a natural product (Gerwick, Sparks, 2014; Sparks et al., 2017; Lorsbach et al., 2019; Sparks, Duke, 2021). The clearest case of important herbicides being derived from a natural compound is the triketone HPPD inhibitor herbicides that were derived from the natural triketone allelochemical leptospermone (Lee et al., 1997). This was a new herbicide mode of action when the triketone herbicides were introduced. Other resemblances of commercial herbicides to natural compounds may be by chance, as there is no public documentation of their derivatization from a natural molecule. Two examples of this are the strong resemblances of the herbicide endothall to the natural compound cantharidin from insects, which is also very phytotoxic (Bajsa et al., 2012), and of the herbicide cinmethylin to the monoterpene 1,4-cineole (May et al., 1985; Vaughn, Spencer, 1993). Both of these have modes of action that are unique among herbicides. Cinmethylin inhibits acyl-ACP thioesterase (Campe et al., 2018) and endothall inhibits serine/threonine protein phosphatase (Bajsa et al., 2012). These modes of action were not clearly determined and recognized by the Herbicide Resistance Action Committee (2021) until decades after they were first commercialized, so at the farm level, these are not really new modes of action.

There are cases of potent natural phytotoxins with new molecular target proteins that might be modified to improve their physicochemical properties and/or to reduce the cost of production of the compound. For example, the microbial tetrapeptide tentoxin inhibits $\mathrm{CF}_{1}$ ATPase of the chloroplast and is active on key weed species at low concentrations and is harmless to maize and soybean (Duke, 1986; Lax et al., 1988); however, it is extremely expensive. Efforts have been made to make analogs to reduce the cost and improve the herbicidal activity of this molecule (e.g., Edwards et al., 1987). Similarly, the potent microbial phytotoxin hydantocidin that kills plants by inhibition of adenylosuccinate synthetase (Cseke et al., 1996; Heim et al., 1995; Siehl et al., 1996) was the focus of numerous attempts to create more effective herbicides (e.g., Harrington, Jung, 1994). Hydantocidin is a proherbicide that must be phosphorylated to inhibit its target enzyme (Fonné-Pfister et al., 1996; Heim et al., 1995; Siehl et al., 1996). This enzyme target is not used by any commercial herbicide. These are examples of potential herbicides with new modes of action that would be very useful in managing evolution of herbicide resistance, even though new modes of action alone are not a panacea for this problem (Gaines et al., 2021).

There are also examples of natural phytotoxins that have modes of action of commercial herbicides, but bind the molecular target differently than commercial herbicides, making target site-resistant weeds susceptible to them. For example, the fungal metabolite tenuazonic acid is a PSII inhibitor that binds the D1 differently than triazine herbicides (Chen, Quiang, 2017, Chen et al., 2007). Derivatives of this compound have been patented as herbicides (Chen, Quiang, 2017). Tenuazonic acid itself is a good herbicide in cotton which is naturally tolerant to it (Zhou et al., 2019).

\subsection{Used to identify new herbicide targets}

Herbicides with new herbicide modes of action are in great demand because of the evolution of weed resistance to herbicides from almost all mode of action classes (Heap, Duke, 2018; Gaines et al., 2020) and the lack of commercial herbicides with new modes of action over the last 30 years (Duke, 2012; Qu et al., 2021). Therefore, herbicides with new molecular targets are needed for herbicide resistance 
management strategies. One approach to achieve this goal is to establish that inhibition of a new molecular target will kill plants. For several possible reasons, not all potential molecular targets are amenable as a herbicide target (Dayan, Duke, 2020). There are, however, many natural compounds that kill plants through inhibition of enzymes of molecular targets that are not one of those of commercial herbicides, indicating that these are potentially good targets for focusing herbicide discovery. Dayan and Duke (2014) reviewed the molecular targets of natural herbicidal compounds known at that time, describing many that have potential for the development of new herbicides. We will not repeat this extensive review, but since this review was published, several new molecular targets of microbial metabolite phytotoxins have been published that we cover below. We also discuss some older compounds not covered in previous reviews.

Compounds that have not received significant recognition in previous reviews are the phytotoxic naphthopyranone derivative compounds from the coprophilous fungus Guanomyces polythrix (Macías et al., 2001). These compounds appear to act primarily through interference with calmodulin (Mata et al., 2003), a novel target for a herbicide. Martínez-Luis et al. (2007) discuss several natural compounds that may act as phytotoxins by interfering with calmodulin function.

Aspterric acid (Figure 1), a phytotoxic, sesquiterpene metabolite of several fungi, was found to be a potent inhibitor of the last enzyme of the branched chain amino acid pathway, dihydroxy acid dehydratase (DAD) (Yan et al., 2018). As pointed out by Duke et al. (2019b), this compound is herbicidally weak compared to commercial herbicides, although DAD is potentially a good, new target that has been the focus of past company herbicide discovery efforts.

The cyanobacterial non-primary metabolite sugar, 7-deoxy-sedoheptulose (Figure 1), was found to be phytotoxic by inhibition of 3-dehydroquinate synthase, the second enzyme of the shikimate pathway (Brislisauer et al., 2019). Its activity on Arabidopsis thaliana seedling growth was similar to, if not greater than, that of glyphosate, another inhibitor of an enzyme (5-enolpyruvylshikimate-3-phosphate synthase) of the shikimate pathway that is the most successful herbicide in the world (Duke, Powles, 2008).

Romidepsin (Figure 1), one of two phytotoxic natural compounds from a biopesticide based on the soil microbe Burkholderia rinojensis (see Section 3), inhibits plant histone deacetylases (HDAs) (Owens et al., 2020). It is highly active on $A$. thaliana $\left(\mathrm{IC}_{50}=0.19 \mu \mathrm{M}\right)$ and is seven-fold more active on HDAs in the reduced than the oxidized form. The aminophenoxazinone compound 2-amino-3H-phenoxazin3-one (APO), which is produced by soil microbes through metabolism of the plant-produced benzoxazinoid allelochemical 4-dihydroxy2H-1,4-benzoxazin-3(4H)-one (DIBOA) (Macías et al., 2005b), is also a HDA inhibitor (Venturelli et al., 2015), although it is weaker than romidepsin as both a phytotoxin and a HAD inhibitor. However, APO is a stronger phytotoxin than DIBOA (Macías et al., 2005a).

A complication in determining the mode of action of some natural compounds as herbicides is that they may have more than one molecular target. For example, the relatively potent allelochemical sorgoleone inhibits PSII, mitochondrial electron transport, $\mathrm{HPPD}$, and root $\mathrm{H}^{+}$ ATPase activity (Dayan et al., 2010). However, there are no papers that demonstrate multiple modes of action at a single concentration under realistic field conditions. In the case of sorgoleone, PSII appears the be the dominant mode of action in seedlings, with additional modes of action being involved in older plants (Dayan et al., 2009). Similarly, the natural phytotoxins linarin (Figure 1), a flavone phytochemical, (Rios et al., 2018) and 3-acetyl-5-isopropyltetramic acid (Chen et al., 2011), both PSII inhibitors, also appear to have other modes of action. The multiple modes of action of sarmentine (Dayan et al., 2015) are discussed above. For natural products that are the result of their evolution to be phytotoxic, the evolutionary process occurred over a much longer period than that of the use of synthetic herbicides, so avoidance of evolved target site resistance to them would favor compounds with multiple modes of action. As mentioned earlier, no synthetic herbicides have multiple modes of action at recommended application rates, but, considering the current herbicide resistance problems, a compound with multiple modes of action would be highly desirable (Gressel, 2020).

Clearly, a synthetic compound that effectively inhibits the targets of natural phytotoxins that kill plants at low concentrations could be a desirable commercial herbicide with a new mode of action if its cost is not prohibitive and its toxicological profiles (human and environmental) are benign. Natural products provide better clues to targets for herbicides than other strategies such as knocking out genes for potential targets. The limitations of the gene knockout approach are detailed by Duke et al. (2009).

\section{Microbial Bioherbicides}

Microbial bioherbicides, as defined by the United States Environmental Protection Agency, are live or killed microbes that are applied to kill or manage weeds. To our knowledge, regulatory agencies in other parts of the world do not consider killed microbe preparations to be microbial bioherbicides. Most of the effort with such products has been with live microbes, using either an inoculative or inundative approach. The inoculative approach is to introduce a microbe to an area infested by the target weed(s) and let it spread. This approach has been used primarily for management of invasive weeds in non-crops settings (Morin, 2020). This type of classical biocontrol is not suitable for most crops, especially annual crops, as the spread and action of the microbe are usually too slow to sufficiently protect a crop during a production season. Also, 
if successful, the microbe can become native to the treated area, so that more of the bioherbicide is not needed - a disincentive for commercialization. The microbe of choice for the inoculative approach is usually one from the center of origin of the invasive weed. There are ecological risks to introduction of a microbe into a habitat in which it has never existed. Also, the Nagoya Protocol has complicated use of microbes from the country or countries of origin in countries where the microbe is not found (Copping, 2015).

The inundative approach has been to treat an agricultural field with a formulation of an indigenous plant pathogen that is harmless to the crop and to nearby non-weed plant populations. The application is much like that of a chemical herbicide, not spreading significantly to plants that are not sprayed. In most cases, the pathogen has been a fungus, formulated as a mycelial, conidia, or spore preparation. One viral (Tobacco mild green mosaic virus) and three bacterial microbial (Xanthomonas campestris pv. poae, Pseudomonas fluorescens and Streptomyces scabies) bioherbicides have been developed (Table 1). Most of these products that were available are no longer sold. Several living microbial bioherbicides have been approved for commercial use and marketed, but their use has been very limited for several reasons. Examples of most of these are in Table 1.

At the time of the review of Morin (2020), only three of the products were commercially available. Many other microbes have been suggested as potential microbial bioherbicides. For example, Dalinova et al. (2020) provide a list of Alternaria species with potential as mycoherbicides. Unfortunately, considerable effort and money has been spent on some of those listed (e.g., A. cassia, and A. destruens) without a viable commercial product being produced. With the increasing cascade of evolved resistance to synthetic herbicides (Heap, Duke, 2018), some of these might be reexamined, especially those that target weeds species that have become major problems across wide areas because of evolved herbicide resistance. The A. alternata pathovars that infect Amaranthus retroflexus (Lawrie et al., 2000) and Echinocloa spp. (Motlagh, 2012) are examples of these. Many other genera of fungi have been researched for use as mycoherbicides without a commercial success. Examples of these are Stagonospora cirsii for Cirsium arvense control (Sokornova, Berestetskiy, 2018) and Colletotrichum truncatum for control of Bidens (Vieira et al., 2018) and Sesbania species (Weaver et al., 2007). Several of these studied, but not commercialized species before 2015 are listed by Harding and Raizada (2015).

A living microbial bioherbicide is attractive in the USA for three major reasons (Table 2). First, the cost of development and regulatory approval is significantly less (usually a few million \$USD) than that of chemical herbicides for which this cost is hundreds of millions of \$USD (Marrone, 2019). Second, if the product is not genetically engineered or formulated with synthetic chemicals, it can be accepted by organic farmers. Third, it should leave no chemical residues in the crop. There exists a huge market potential for an economical and efficacious microbial bioherbicide. Additionally, there is still no evolved resistance to such products. Most of the companies involved in discovery and development of these products are in North America, in large part because the regulatory climate for their approval is more favorable than in other parts of the world, such as the European Union (Balog et al., 2017, Damalas, Koutroubas, 2017).

However, there are many limitations of microbial bioherbicides (Table 2), and, because of these, there are few successful products of this type. For unclear reasons, there has been much more success with microbial biopesticides that target insect and plant pathogen pests (Marrone, 2019), and, thus, reviews of microbial biopesticides rarely, if at all, mention microbial bioherbicides (e.g., Ruiu, 2018; Thakur et al., 2020). The limitations were reviewed over 25 years ago by Auld and Morin (1995). Many of these limitations were further discussed by Boyetchko and Peng (2003) and Hallett (2005) a decade later and more recently by Harding and Raizada (2015), Cordeau et al. (2016), Watson (2018), Morin (2020), Berestetskiy (2021) and Hasan et al. (2021). These limitations still exist, but recently developed technologies might help to overcome them.

First, the plant pathogens used most always have a very limited host range. This provides some assurance that it will not spread to non-weed plants, but if only one or two weed species are targeted, rather than many weeds species, the cost of the bioherbicide and applying it may not justify its use. An exception to this problem is Phoma macrostoma (Table 1 ) which is effective on at least 38 dicot weed species (Bailey et al., 2011). Research has been conducted to increase host range and virulence by genetic modification of the microbe (e.g., Greaves et al., 1989; Sands, Miller, 1993; Amsellem et al., 2002). However, the potential for environmental mishap with this approach is much higher than that of genetically engineered crops. Improved formulations can extend the host range and/or increase the virulence of mycoherbicides on normally non-target weed species (e.g., Boyette, Abbas, 1994; Boyette et al., 1996; 2019). This approach is less risky, but more limited in what can be accomplished.

There are significant problems with living products. These include a limited shelf life and more limited storage conditions, lack of compatibility with other pesticides, and the need for a specific, well-defined microenvironment for the microbe to infect the target weed. Shelf life and storage conditions can be improved by formulation (Amsellem et al., 1999; Zidack, Quimby, 2002), freeze drying (Hoagland et al., 2017), and by low temperatures and a modified atmosphere in the packaging (Teshler et al., 2007). These problems are less with viral, microbial bioherbicides such as Tobacco mild green mosaic virus for control of tropical soda apple (Solanum viarum) (Charudattan, 2007).

To effectively infect the target weed, the microbe propagule must have a proper microenvironment for a sufficient period of time to germinate and/or grow and infect 
Table 1 - Examples of microbial bioherbicides for use in agriculture that have been commercialized at one time or gotten to the trade name stage. Some of the products were reintroduced with new trade names

\section{Microbe \& Ref.}

Alternaria cossio

Bannon 1988

Alternario destruens

Bewick et al. 2000

Chondrostereum pupureum

Hintz 2007

Colletotrichum ocutotum

Morris 1989

Colletotrichum gloeosporiodides

f. sp. aeschynomene

Cartwright et al. 2010

Colletotrichum gloeosporiodides

f. sp. malvoe

Boyetchko et al. 2007

Cylindrobosidium leove

Morris et al. 1999

Phoma macrostomo

Bailey et al. 2011

Phytophthoro palmivoro

Ridings 1986

Pseudomonas fluorescens

Kennedy et al. 2001

Puccinio conaliculato

Phatak et al. 1983

Puccinia thlospeos

Knopp et al. 2002

Sclerotina minor

Watson2018

Streptomyces scabies

O'Sullivan et al. 2015

Tobacco mild green mosaic vírus

Charudattan \& Hiebert 2007

Xonthomonos compestris pv. pooe

Imaizaumi et al. 1999

Several fungi

Gale \& Goutler 2013
Weed target(s) \& Status

Trade name

Year of Introduction or registration

\section{Cossio obtusifolio \\ C. coccidentalis}

Crotolorio spectabilis

Never commercialized

Cusucto spp.

Discontinued

Smolder ${ }^{T M}$

2005

Populus and Alnus spp.

$$
\text { Unknown }
$$

Chontrol $^{\mathrm{TM}}$

2004

Hakeo sericeo

Discontinued

Hakatak $^{\text {TM }}$

1990

Aeshynomene vigrinico

Available on demand

Collego ${ }^{\circledR}$

1982

Acocio mearnsii and

A. pycnantho

Discontinued

Stumpout ${ }^{\text {TM }}$

1997

Acacio mearnsii and A. pycnontho

Discontinued

Stumpout ${ }^{\mathrm{TM}}$

1997

many broadleaf weed species

Available

Bio-Phoma ${ }^{\text {TM }}$

2016

Morrentio oderato

Discontinued

DeVine $^{\oplus}$

1982

Bromus tectorum

Discontinued

D7 ${ }^{\circledast}$

2014

Cyperus esculentus

Discontinued

Isatis tinctorial

Discontinued

Taraxacum officinale

Discontinued

several grass and broadleaf weeds

Never commercialized

Solanum viarum

Available

Dr. Biosedge $\mathrm{T}^{\mathrm{M}}$

1987

Woad Warrior ${ }^{\circledR}$

2002

Sarritor ${ }^{\circledast}$

2009

Poo annuo

Discontinued?

Parkinsonio oculeate

Available
Opportune TM $^{\mathrm{T}}$

2012

SolviNix ${ }^{T M}$

2014

Camperico $^{\mathrm{TM}}$

1997

Di-Bak ${ }^{\circledast}$

2019

Source: Adapted in part from Watson (2018) and Morin (2020)

that weed. Those involved in development of plant growthand health-promoting microbes for crops have had to deal with similar problems, although these microbes infect the root, where maintaining a proper microenvironment is not as difficult as for foliar-applied microbes (Zvinavashe et al., 2021). The microenvironment problem can be partially overcome by a formulation that provides the proper microclimate when applied. For example, a gel that does not 
Table 2 - Advantages and disadvantages of living microbial bioherbicides

\begin{tabular}{|l|c|}
\hline Advantage & \multicolumn{1}{c}{ Disadvantage } \\
\hline $\begin{array}{l}\text { Low development cost } \\
\text { Low cost of regulatory } \\
\text { approval } \\
\text { Good public acceptance }\end{array}$ & Narrow host range \\
\hline No chemical residues & $\begin{array}{c}\text { Special storage conditions } \\
\text { Special formulation an application } \\
\text { technology }\end{array}$ \\
\hline Narrow host range & $\begin{array}{r}\text { Required microenvironment for } \\
\text { infectivity }\end{array}$ \\
\hline Approved for organic farming & $\begin{array}{c}\text { Quality control issues } \\
\text { No evolved resistance yet }\end{array}$ \\
\hline $\begin{array}{l}\text { Low mammalian and } \\
\text { ecotoxicity }\end{array}$ & $\begin{array}{c}\text { Efficacy is usually poorer than } \\
\text { chemical herbicides }\end{array}$ \\
\hline
\end{tabular}

dry out quickly, providing enough moisture and nutrients for the microbe to grow and infect the weed can be used. Another example is an invert emulsion formulation that can retard evaporation, allowing the fungal propagule more time to germinate and/or grow and infect the host weed (Daigle et al., 1989). Unfortunately, such formulations with high viscosity usually require air-assist spray systems that are more expensive and complicated than standard spray systems. This specialized application technology contributes to the reluctance to use a bioherbicide that kills only one or a very few weed species.

Certain co-formulated chemicals can improve the efficacy of live microbial bioherbicides. For example, the use of a low dose of glyphosate with a mycoherbicide was almost commercialized (Christy et al., 1993). In some cases, a low glyphosate dose synergizes mycoherbicides by reducing the production of weed phytoalexins and other defensive compounds (e.g., lignin) derived from the shikimate pathway (Gressel, 2010, Duke, 2018b). Such a product would not have been used by organic farmers, but would be suitable for farmers wishing to reduce herbicide residues in marketed crops, the major market for bioherbicides (Marrone, 2019). Glyphosate and a mycelial preparation of Myrothecium verrucaria synergistically managed the hardto-kill perennial weeds redvine (Brunnichia ovata), kudzu (Pueraria lobata), and trumpet creeper (Campsis radicans) (Boyette et al., 2006; 2020). Others (Mitchell et al., 2008) foundapplication of subtoxicglyphosatedoses to shattercane (Sorghum bicolor (L.) Moench.) before application of the two proposed mycoherbicides Colletotrichum graminicola and Gloeocercospora sorghi enhanced their efficacy, but there was antagonism if the order of application was reversed. Similarly, Boyette et al. (2008) found application of low doses of glyphosate (150 $\left.\mathrm{g} \mathrm{ha}^{-1}\right)$ applied before low doses $\left(1.25 \times 10^{6}\right.$ spores $\left.\mathrm{mL}^{-1}\right)$ of the mycoherbicide Colletotrichum truncatum to hemp sesbania (Sesbania herbacea) provided a greater herbicidal effect than the added effect of the two treatments alone. No more than an additive effect occurs when glyphosate and the microbe were applied together or when the microbe was applied before glyphosate. Commercial "inert" formulation ingredients of glyphosate can be incompatible with mycoherbiides. For example, Hoagland et al. (2018a) found technical grade glyphosate to synergize the efficacy of $M$. verrucaria on palmer amaranth (Amaranthus palmeri) when formulated together, but some commercial formulations of glyphosate inhibit the fungus. Peng and Wolf (2011) give examples additive or synergistic interactions of Pyricularia setariae and sethyoxydim on green foxtail (Setaria veridis) and other weed species, as well as positive interactions of Colletotrichum truncatum and metribuzin, 2,4-D, clopyralid, and MCPA on scentless chamomile (Matricaria perforata).

Even though a herbicide or other chemical may synergize the efficacy of a microbial bioherbicide by effects on the target weed, it might also antagonize some plant pathogens by direct effects on the microbe (Duke, 2018b). For example, Hoagland et al. (2018b) found glufosinate did not synergize the mycoherbicide $C$. truncatum when glufosinate was applied in combination with sub-lethal spore concentrations of the bioherbicidal fungus in experiments with hemp sesbania. However, glufosinate incorporated in a growth agar medium at $0.25 \mathrm{mM}$ to 2.0 $\mathrm{mM}$, caused a $10 \%-45 \%$ reduction of $C$. truncatum colony radial growth, compared to fungal growth on agar without glufosinate, and the herbicide also inhibited sporulation of this fungus. This agrees with other findings, in which glufosinate inhibited or suppressed fungal growth and disease severity of several different plant pathogens such as Pythium ultimum (Liu et al., 1997), Magnaporthe grisea (Tada et al., 1996), Cochliobolus miyabeanus (Ahn, 2008), and Rhizoctonia solani (Wang et al., 2003).

Fungicidal effects or some herbicides are not surprising, as fungi have some of the same enzymes targeted by herbicides in plants. A solution to this type of antagonism could be to genetically engineer the microbe to be resistant to the herbicide or chemical. For example, Brooker et al. (1996) inserted the bar gene for bialaphos/glufosinate resistance into the mycoherbicide Colletotrichum gloeosporioides $\mathrm{f}$. sp. aeschynomene (Table 1) to make it compatible with bialaphos. They found that the transformant and bialaphos were synergistic, allowing reduced application rates of both the mycoherbicide and the natural product herbicide.

Another problem is the quality control of fermentation products. There can be problems with producing sufficient mycelia, spores, or conidia, loss of virulence over time, and poor viability of mycelia, spores or conidia. If the presence of phytotoxins is required for the activity of the product, whether dead or alive, fermentation conditions can greatly alter their presence and quantity (e.g., Portela et al., 2020).

Despite all these problems, several living microbial bioherbicides have been commercialized or almost commercialized, although almost all of those previously brought to market are no longer available (Table 1). This is 
primarily because of a combination of relatively high cost for relatively limited or poor performance. Considering their highest pest management costs are for control of weeds, many organic farmers would pay a premium for an efficacious product that kills a major problem weed.

In the USA, microbial bioherbicides can be composed of killed microbes. In such cases, the killed microbial formulation must contain a microbially-produced phytotoxin or phytotoxins. This type of product has several clear advantages over a living microbe. Such a product could be handled and applied in much the same way as a conventional herbicide, and there would be no risk of disease spread to non-target plants. Storage conditions, shelf-life, formulation, compatibility with agrochemicals, and infectivity are not problems or are lesser problems. Furthermore, the phytotoxins produced by microbes are often effective on a much wider range of weed species than the living plant pathogen.

A killed potato scab bacterium (Streptomyces acidiscabies) preparation containing the strong phytotoxin thaxtomin has been developed (Opportune ${ }^{\mathrm{TM}}$ ). Thaxtomin $A$ is a potent cellulose synthesis inhibitor, that apparently binds a different binding site than the commercial synthetic cellulose synthetase inhibitor isoxaben (Scheible et al., 2003; Tegg et al., 2013). Thaxtomin A provides effective, selective broadleaf weed control in turfgrass (Wolfe et al., 2016a), with some control of smooth crabgrass (Digitaria ischaemum) in some turfgrasses (Wolfe et al., 2016b). The killed $S$. acidiscabies product is being developed for use in rice and other cereals.

An example of such a potential product is a preparation of the soil microbe Burkholderia rinojensis (Marrone, 2019). It contains both the phytotoxins romidepsin and spliceostatin $C$. These compounds are quite potent on Amaranthus species. They have entirely new modes of action, with romidepsin inhibiting histone demethylase (Owens et al., 2020) and spliceostatin $C$ inhibiting the function of the spliceosome (Bajsa-Hirschel et al., 2019).

As discussed in section 2.2, many microbes produce potent phytotoxins, so if cultured under conditions favorable for production of high levels of the phytotoxins, these microbes may have use in killed microbe preparations of a microbial bioherbicide. Such products could be mixed to expand the range of weed species that could be managed. Some previously commercialized microbial bioherbicides might be more viable products if they were grown to maximize phytotoxin production and applied as a killed microbe formulation, thus eliminating issues associated with a live organism. For example, Phoma macrostoma produces highly phytotoxic macrocidins that have been studied as the basis for standalone chemical herbicides (Graupner et al., 2006).

\section{Conclusions}

There is a great need for new weed management options in crops that can be provided by both natural phytotoxins and microbial bioherbicides. Compared to products for insect and crop pathogen management, these tools have been underutilized for weed management. Natural phytotoxins can be used directly as herbicides, but this approach has not been as successful as using them as templates for synthetic herbicides. They can also be used for discovery of new modes of action and molecular targets for future herbicides. Development and regulatory approval of microbial bioherbicides for inundative use in crops is relatively inexpensive. Additionally, they have low environmental impact and good public acceptance. Despite these advantages, their success has been limited by narrow host specificity, quality control, short shelf life, microenvironment requirements, and variable efficacy. New technologies can overcome these problems. In the U.S.A., microbial bioherbicides can be preparations of killed microbes containing phytotoxins produced before the microbes are killed. This approach eliminates some of the disadvantages of applying live organisms. Natural product and microbe-based or -inspired weed management should play a larger future role.

\section{Author's contributions}

All authors read and agreed to the published version of the manuscript. SOD, ZP, JB-H, and CDB: conceptualization of the manuscript and the writing of it.

\section{References}

Ahn IP. Glufosinate ammonium-induced pathogen inhibition and defense responses culminate in disease protection in bor-transgenic rice. Plant Physiol. 2008;146(1):313-27. Available from: https://doi.org/10.1104/pp.107.105890

Amsellem Z, Zidack NK, Quimby P, Gressel J. Long-term dry preservation of viable mycelia of two mycoherbicide organisms. Crop Protect. 1999;18(10):643-9. Available from: https://doi.org/10.1016/ S0261-2194(99)00070-8

Amsellem Z, Cohen BA, Gressel J. Engineering hypervirulence in a mycoherbicidal fungus for efficient weed control. Nat Biotechnol. 2002;20(10):1035-9. Available from: https://doi.org/10.1038/nbt743
Auld BA, Morin L. Constraints in the development of bioherbicides. Weed Technol. 1995;9(3):638-52. Available from: https://doi. org/10.1017/S0890037X00023964

Bailey KL, Pitt WM, Falk S, Derby J. The effects of Phomo mocrotomo on nontarget plant and target weed species. Biol Control. 2011;58(3):379-86. Available from: https://doi.org/10.1016/j. biocontrol.2011.06.001

Balog A, Hartel T, Loxdale HD, Wilson K. Difference in the progress of the biopesticide revolution between the EU and other major crop-growing regions. Pest Manag Sci. 2017;73(11):2203-8. Available from: https://doi.org/10.1002/ps.4596 
Bajsa J, Pan Z, Dayan FE, Owens DK, Duke SO. Validation of serine/ threonine protein phosphatase as the herbicide target site of endothall. Pestic Biochem Physiol. 2012;102(1):38-44. Available from: https://doi.org/10.1016/j.pestbp.2011.10.007

Bajsa-Hirschel J, Boddy L, Sabat M, Pan Z, Stephen SO. Splicing inhibition is responsible for spliceostatin $C$ phytotoxicity. In: Abstract of American Chemical Society Meeting; San Diego, United States of America. New York: American Chemical Society; 2019.

Bannon JS. CASST ${ }^{\mathrm{TM}}$ herbicide (Alternaro cossia): a case history of a mycoherbicide. Am J Alt Agric. 1988;3(2-3):73-6. Available from: https://doi.org/10.1017/S0889189300002216

Berestetskiy A. Development of mycoherbicides. In: Zaragoza 0 , Casadevall A, editors. Encyclopedia of Mycology. Vol. 2. Amsterdam: Elsevier; 2021. p. 629-40.

Bewick TA, Porter JC, Ostrowski RC. Smoler ${ }^{\mathrm{TM}}$ : a bioherbicide for suppression of dodder (Cuscuto spp.). Proceedings of 53rd Annual Meeting of South Weed Science Society; Tulsa, United States of America. Westminster: South Weed Science Society; 2000. p. 152

Bingamen BR, Christians NE. Greenhouse screening of corn gluten meal as a natural control product for broadleaf and grassy weeds. Am Soc Hort Sci. 1995;30(6):331-40. Available from: https://doi.org/10.21273/HORTSCI.30.6.1256

Boyd NS, Brennan EB, Fennimore SA. Stale seedbed techniques for organic vegetable production. Weed Technol. 2006;20:1052-7. Available from: https://doi.org/10.1614/WT-05-109.1

Boyette CD, Abbas HK. Host range alteration of the bioherbicidal fungus Alternorio crasso with fruit pectin and plant filtrates. Weed Sci. 1994;42(43):487-91. Available from: https://doi.org/10.1017/ S0043174500076815

Boyette CD, Quimby PC, Caesar AJ, Birdsall JL, Connick WJ, Daigle DJ et al. Adjuvants, formulations, and spraying systems for improvement of mycoherbicides. Weed Technol. 1996;10(3):637-44. Available from: https://doi.org/10.1017/S0890037X00040562

Boyette CD, Reddy KN, Hoagland RE. Glyphosate and bioherbicide interaction for controlling kudzu (Puerorio loboto), redvine (Brunnichio ovoto), and trumpetcreeper (Compsis radicans). Biocont Sci Technol. 2006;16(10):1067-77. Available from: https://doi. org/10.1080/09583150600828742

Boyette CD, Hoagland RE, Weaver MA. Interaction of a bioherbicide and glyphosate for controlling hemp sesbania in glyphosate-resistant soybean. Weed Biol Manag. 2008;8(1):18-24. Available from: https://doi. org/10.1111/j.1445-6664.2007.00269.x

Boyette CD, Hoagland RE, Stetina KC. Extending the host range of the bioherbicidal fungus Colletotrichum gloeosporioides $\mathrm{f}$. $\mathrm{sp}$. aeschynomene. Biocon Sci Technol. 2019;29(7):720-6. Available from: https://doi.org/10.1080/09583157.2019.1581130

Boyette CD, Hoagland RE, Bryson CT, Weaver MA, Stetina KC. Interaction of a Myrothecium verrucaria mycelial preparation and a glyphosate product for controlling redvine (Brunnichio ovoto) and trumpet creeper (Compsis radicans). Amer J Plant Sci. 2020;11(2): 201-13. Available from: https://doi.org/10.4236/ajps.2020.112016
Boyetchko SM, Peng G. Challenges and strategies for development of mycoherbicides. In: Arora DK, editor. Fungal biotechnology in agricultural, food, and environmental applications. Vol 2. New York: Marcel Dekker; 2003. p. 111-21.

Boyetchko SM, Bailey KL, Hynes RK, Peng G. Development of biomal. In: Vincent C, Goettel MS, Lazarovits G, editors. Biological control: a global perspective. Wallingford: CABI; 2007. p. 274-83.

Brislisauer K, Rapp J, Rath P, Schöllhorn A, Bleul L, Weiß E et al. Cyanobacterial antimetabolite 7-deoxy-sedoheptulose blocks the shikimate pathway to inhibit the growth of prototrophic organisms. Nat Comm. 2019;10:1-11. Available from: https://doi.org/10.1038/ s41467-019-08476-8

Brooker NL, Mischke CF, Patterson CD, Mischke S, Bruckart WL, Lydon J. Pathogenicity of bar-transformed Colletotrichum gloeosporioidses $\mathrm{f}$. sp. aeschynomone. Biol Con. 1996;7:159-66.

Campe R, Hollenbach E, Kämmerer L, Hendriks J, Höffken HW Kraus $\mathrm{H}$ et al. A new herbicidal site of action: cinnmethylin binds to acyl-ACP thioesterase and inhibits plant fatty acid biosynthesis. Pestic Biochem Physiol. 2018;148:116-25. Available from: https://doi.org/10.1016/j.pestbp.2018.04.006

Cartwright K, Boyette D, Roberts M. Lockdown: Collego bioherbicide gets a second act. Phytophathology. 2010;100:S162.

Charudattan R, Hiebert E. A plant virus as a bioherbicide for tropical soda apple, Solonum viorum. Outlooks Pest Manag. 2007;18(4):167-71. Available from: https://doi.org/10.1564/18aug07

Chen S, Qiang S. Recent advances in tenuazonic acid as a potential herbicide. Pestic Biochem Physiol. 2017;143:252-7. Available from: https://doi.org/10.1016/j.pestbp.2017.01.003

Chen S, Xu X, Dai X, Yang C, Qiang S. Identification of tenuazonic acid as a novel type of natural photosystem ॥ inhibitor binding $\mathrm{Q}_{\mathrm{B}}$-site of Clamydomonos reinhardtii. Biochim Biophys Acta. 2007;1767(4):306-18. Available from: https://doi.org/10.1016/j.bbabio.2007.02.007

Chen SG, Zhou FY, Yin CY, Strasser RJ, Yang CL, Qiang S. Application of fast chlorophyll a fluorescence kinetics to probe action target of 3-acetyl-5-isopropyltetramic acid. Environ Exp Bot. 2011;71:269-79. Available from: https://doi.org/10.1016/j.envexpbot.2011.08.005

Copping LG. Biopesticides: new solutions for old problems. Outlooks Pest Manag. 2015;25(6):281-6. Available from: https://doi. org/10.1564/v26_dec_13

Copping LG, Duke SO. Natural products that have been used commercially as crop protection agents. Pest Manag Sci. 2007;63(6):524-54. Available from: https://doi.org/10.1002/ps.1378

Christy AL, Herbst KA, Koska SJ, Mullen JP, Carlson PS. Synergizing weed biocontrol control agents with chemical herbicides. Am Chem Soc Symp Ser. 1993;(524):87-100.

Cordeau S, Triolet M, Wayman S, Steinberg C, Guillemin JP. Bioherbicides: dead in the water? A review of existing products for integrated weed management. Crop Prot. 2016;87:44-9. Available from: https://doi.org/10.1016/j.cropro.2016.04.016 
Cseke C, Gerwick BC, Crouse GD, Murdoch MG, Green SB, Heim DR. $2 \alpha$-phosphohydantocidin: the in vivo adenylosuccinate synthetase inhibitor responsible for hydantocidin phytotoxicity. Pestic Biochem Physiol. 1996;55(3):210-17. Available from: https://doi.org/10.1006/ pest.1996.0050

Daigle DJ, Connick WJ, Quimby PC, Evans JP, Trask-Merrell B, Fulgham FE. Invert emulsions: delivery system and water source for the mycoherbicide, Alternaria cossio. Weed Technol. 1989;3(2):442-4. Available from: https://doi.org/10.1017/S0890037X00025483

Dalinova AA, Salinova DR, Berestetskiy AO. Fungi of the genera Alternorio as produccers of biologically active compounds and mycoherbicides. Appl Biochem Microbiol. 2020;56:256-72. Available from: https://doi.org/10.1134/S0003683820030023

Damalas CA, Koutroubas SD. Current status and developments in biospesticide use. Agriculture. 2018;8(1):1-6. Available from: https://doi. org/10.3390/agriculture8010013

Dayan FE, Duke SO. Natural products for weed management in organic farming in the USA. Outlooks Pest Manag. 2010;21(4):156-60. Available from: https://doi.org/10.1564/21aug02

Dayan FE, Duke SO. Natural compounds as next generation herbicides. Plant Physiol. 2014;166(3):1090-105. Available from: https://doi. org/10.1104/pp.114.239061

Dayan FE, Duke SO. Discovery of new herbicide sites of action by quantification of plant primary metabolite and enzyme pools. Engineering. 2020;6(5):509-14. Available from: https://doi.org/10.1016/j. eng.2020.03.004

Dayan FE, Watson SB. Plant cell membrane as a marker for light-dependent and light-independent herbicide mechanisms of action. Pestic Biochem Physiol. 2011;101(3):182-90. Available from: https://doi. org/10.1016/j.pestbp.2011.09.004

Dayan FE, Duke SO, Sauldubois A, Singh N, McCurdy C, Cantrell CL. $p$-Hydroxyphenylpyruvate dioxygenase is a target site for $\beta$-triketones from Leptospermum scoparium. Phytochemistry. 2007;68(14):200414. Available from: https://doi.org/10.1016/j.phytochem.2007.01.026

Dayan FE, Howell J, Weidenhamer JD. Dynamic root exudation of sorgoleone and its in planta mechanism of action. J Exp Bot. 2009;60(7):210717. Available from: https://doi.org/10.1093/jxb/erp082

Dayan FE, Rimando AM, Pan Z, Baerson SR, Gimsing AL, Duke SO. Sorgoleone. Phytochemistry. 2010;71(10):1032-9. Available from: https:// doi.org/10.1016/j.phytochem.2010.03.011

Dayan FE, Howell J, Marais JP, Ferreira D, Koivunen M. Manuka oil, a natural herbicide with preemergence activity. Weed Sci. 2011;59(4):4649. Available from: https://doi.org/10.1614/WS-D-11-00043.1

Dayan FE, Owens DK, Watson SB, Asolkar RN, Boddy LG. Sarmentine, a natural hebicide from Piper speies with multiple herbicide modes of action. Front Plant Sci. 2015;6:1-11. Available from: https://doi. org/10.3389/fpls.2015.00222.

Duke SO. Microbial phytotoxins as herbicides: a perspective. In: Putnam AR, Tang CS, editors. The science of allelopathy. London: Wiley; 1986. p. 287-304.
Duke So. Why have no new herbicide modes of action appeared in recent years? Pest Manag Sci. 2012;68(4):505-12. Available from: https://doi.org/10.1002/ps.2333

Duke SO. The history and current status of glyphosate. Pest Manag Sci. 2018a;74(5):1027-34. Available from: https://doi.org/10.1002/ps.4652

Duke SO. Interaction of chemical pesticides and their formulation ingredients with microbes associated with plants and plant pests. J Agric Food Chem. 2018b;66:753-61. Available from: https://doi. org/10.1021/acs.jafc.8b02316

Duke SO, Powles SB. Glyphosate: a once in a century herbicide. Pest Manag Sci. 2008;64(4):319-25. Available from: https://doi. org/10.1002/ps.1518

Duke SO, Baerson SR, Gressel J. Genomics and weeds: a synthesis. In: Stewart CN, editor. Weedy and invasive plant genomics. Singapore: Blackwell; 2009. p. 221-47.

Duke SO, Owens DK, Dayan FE. Natural product-based chemical herbicides. In: Korres NE, Burgos NR, Duke SO, editors. Weed control: sustainability, hazards and risks in cropping systems worldwide. Boca Raton: CRC; 2019a. p. 153-65

Duke SO, Stidham MA, Dayan FE. A novel genomic approach to herbicide and herbicide mode of action discovery. Pest Manag Sci. 2019b;75(2):314-7.

Edwards JV, Lax AR, Lillehoj EB, Boudreaux GJ. Structure-activity relationships of cyclic and acyclic analogues of the phytotoxic peptide tentoxin. J Agric Food Chem. 1987;35(4):451-6.

Fagodia SK, Singh HP, Batish DR, Kohli RK. Phytotoxicity and cytotoxicity of Citrus aruantiifolia essential oil and its major constituents: limonene and citral. Indust Crops Prod. 2017;108:708-15. Available from: https://doi.org/10.1016/j.indcrop.2017.07.005

Fonné-Pfister R, Chemla P, Ward E, Giradet M, Kreuz KE, Honzatko $\mathrm{RB}$ et al. The mode of action and the structure of a herbicide in complex with its target: binding of activated hydantocidin to the feedback regulation site of adenylosuccinate synthetase. Proc Natl Acad Sci USA. 1996;93(18):9431-46. Available from: https://doi.org/10.1073/ pnas.93.18.9431

Gaines TA, Duke So, Morran S, Rigon C, Tranel PJ, Küpper A et al. Mechanisms of evolved herbicide resistance. J Biol Chem. 2020;295(30):10307-30. Available from: https://doi.org/10.1074/jbc. REV120.013572

Gaines TA, Busi R, Kuepper A. Can new herbicide discovery allow weed management to outpace resistance evolution? Pest Manag Sci. 2021;77(7):3036-41. Available from: https://doi.org/ 10.1002/ps.6457

Galea V, Goutler K. Field evaluation of a bioherbicide for control of parkinsonia (Parkinsonia oculeote) in Australia. Proceedings of 19th Australasian Plant Pathology Conference; Auckland, New Zealand. Adelaide: Australasian Plant Pathology Society; 2013. p. 43.

Gerwick BC, Sparks TC. Natural products for pest control: an analysis of their role, value and future. Pest Manag Sci. 2014;70(8):1169-85. Available from: https://doi.org/10.1002/ps.3744 
Graña E, Días-Tielas C, Sánchez-Moreiras AM, Reigosa $M J$, Celiero $M$, Abagyan $R$ et al. Transcriptome and binding data indicate that citral inhibits single strand DNA binding proteins. Physiol Plant. 2020;169(1):99-109. Available from: https://doi.org/ 10.1111/ppl.13055

Graupner PR, Gerwick BC, Siddall TL, Carr AW, Clancy E, Gilbert JR et al. Chorosis inducing phytotoxic metabolites: new herbicides from Phomo macrostomo. Amer Chem Soc Sym Ser. 2006;927:37-47. Available from: https://doi.org/10.1021/bk-2006-0927.ch003

Greaves MP, Bailey JA, Hargreaves JA. Mycoherbicides: opportunities for genetic manipulation. Pestic Sci. 1989;26(1):93-101. Available from: https://doi.org/10.1002/ps.2780260109

Gressel J. Herbicides as synergists for mycoherbicides, and vice versa. Weed Sci. 2010;58(3):324-8. Available from: https://doi.org/10.1614/ WS-09-071.1

Gressel J. Perpsective: present pesticide discovery paradigms promote the evolution of resistance: learn from nature and prioritize multi-target site inhibitor design. Pest Manag Sci. 2020;76(2):421-5. Available from: https://doi.org/10.1002/ps.5649

Hallett SG. Where are the bioherbicides? Weed Sci. 2005;53(3):40415. Available from: https://doi.org/10.1614/WS-04-157R2

Harding DP, Raizada MN. Controlling weeds with fungi, bacteria and viruses: a review. Front Plant Sci. 2015;6:1-14. Available from: https://doi. org/10.3389/fpls.2015.00659

Harrington PM, Jung ME. US patent No 5354868. Process for the preparation of (+)-hydantocidin and analogs thereof. Alexandria: US Patent; 1994

Hasan M, Ahmad-Hamadani MS, Rosli AM, Hamdan H. Bioherbicides: an eco-friendly tool for sustainable weed management. Plants. 2021;10(6):121. Available from: https://doi.org/10.3390/plants10061212

Hazrati H, Saharkhiz MJ, Niakousari M, Moein M. Natural herbicide activity of Soturejo hortensis L. essential oil nanoemulsion on the seed germination and morphophysiological features of two important weed species. Ecotoxicol Environ Saf. 2017;142:423-30. Available from: https://doi.org/10.1016/j.ecoenv.2017.04.041

Heap I, Duke SO. Overview of glyphosate-resistant weeds worldwide. Pest Manag Sci. 2018;74(5):1040-9. Available from: https://doi.org/10.1002/ps.4760

Heim DR, Cseke C, Gerwick BC, Murdoch MG, Green SB. Hydantocidin: a possible proherbicide inhibiting purine biosynthesis at the site of adenylosuccinate synthetase. Pestic Biochem Physiol. 1995;53(2):138-45. Available from: https://doi.org/10.1006/pest 1995.1061

Hintz W. Development of Chondrostereum purpureum as a mycoherbicide for deciduous brush control. In: Vincent CC, Goettel M, Lazarovits G, editors. Biological control: a global perspective. Wallingford: $\mathrm{CABI}$; 2007. p. 284-90.

Hoagland RE, Boyette CD, Stetina KC. Extending the shelf-life of Myrotheticum verrucario, a bioherbicide. Amer J Plant Sci. 2017;8:3272-84.
Hoagland RE, Boyette $\mathrm{CD}$, Jordan $\mathrm{RH}$, Stetina, $\mathrm{KC}$. Interaction of the bioherbicide Myrothecium verrucario with technical-grade glyphosate on glyphosate-susceptible and -resistant palmer amaranth. Amer J Plant Sci. 2018a;9(11):2306-19. Available from: https://doi. org/10.4236/ajps.2018.911167

Hoagland RE, BoyetteCD, Jordan RH, Stetina KC. Interaction of glufosinate and Colletotrichum truncotum on ammonia levels and glutamine synthetase activity in hemp sesbania. Amer J Plant Sci. 2018b;9(11):2320-37. Available from: https://doi.org/10.4236/ajps.2018.911168

Herbicide Resistance Action Committee - Hrac. Protecting crop yields and quality worldwide. 2021[access Jun 15, 2021]. Available from: http://hracglobal.com

Imaizaumi S, Honda M, Fujimori T. Effect of temperature on the control of annual bluegrass (Poo annua L.) with Xonthomonas compestris pv. poae (JT-P482). Biol Control. 1999;16(1):13-7. Available from: https:// doi.org/10.1006/bcon.1999.0728

Kennedy AC, Johnson BN, Stubbs TL. Host range of a deleterious rhizobacterium for biological control of downy brome. Weed Sci. 2001;49(6):792-7. Available from: https://doi.org/10.1614/0043-1745( 2001)049[0792:HROADR]2.0.C0;2

Knopp BR, Hansen DR, Thomsen SV. Establishmentand dispersal of Puccinio thlospeos in field populations of Dyer's woad. Plant Dis. 2002;86(3):2416. Available from: https://doi.org/10.1094/PDIS.2002.86.3.241

Kuzdraliński A, Solarska W, Mazukiewicz J. Mycotoxin content of organic and conventional oats from southeastern Poland. Food Control. 2013;33(1):68-72. Available from: https://doi.org/10.1016/j.foodcont.2013.02.014

Lawrie J, Down VM, Greaves MP. Factors influencing the efficacy of the potential microbial herbicide Alternorio alternoto (Fr.) Keissler on Amaranthus retroflexus (L.). Biocontrol Sci Technol. 2000;10(1):81-7. Available from: https://doi.org/10.1080/09583150029413

Lax AR, Shepherd HS, Edwards JV. Tentoxin, a chlorosis-inducing toxin from Alternaria as a potential herbicides. Weed Technol. 1988;2(4):5404. Available from: https://doi.org/10.1017/S0890037X00032413

Lee DL, Prisbylla MP, Cromartie TH, Dagarin DP, Howard SW, Provan $W M$ et al. The discovery and structural requirements of inhibitors of p-hydroxyphenylpyruvate dioxygenase. Weed Sci. 1997;45(5):601-9. Available from: https://doi.org/10.1017/S0043174500093218

Liu DLY, Christians NE. Isolation and identification of root-inhibiting compounds from corn gluten hydrolysate. J Plant Growth Regul. 1994;13:227-30. Available from: https://doi.org/10.1007/BF00226041

Liu DLY, Punja ZK, Rahe JE. Altered root exudation and suppression of induced lignification as mechanisms of predisposition by glyphosate of bean roots (Phoseolus vulgoris L.) to colonization by Pythium spp. Physiol Mol Plant Pathol. 1997;51(2):111-27. Available from: https://doi. org/10.1006/pmpp.1997.0113

Lorsbach BA, Sparks TA, Cicchillo RM, Garizi NV, Hahn DR, Meyer KG. Natural products: as strategic lead generation approach in crop protection discovery. Pest Manag Sci. 2019;75(9):2301-9. Available from: https://doi.org/10.1002/ps.5350 
Lydon J, Duke SO. Inhibitors of glutamine synthesis. In: Singh BK, editor. Plant amino acids. New York: Marcel Dekker; 1999. p. 445-64.

Macías FA, Marín D, Oliveros-Bastidas A, Castellano D, Simonet AM, Molinillo JMG. Structure-activity relationships (SAR) studies of benzoxazinone, their degradation products and analogues: phytotoxicity on standard target species (STS). J Agric Food Chem. 2005a;53(3):538-481. Available from: https://doi.org/10.1021/jf0484071

Macías FA, Oliveros-Bastidas A, Marín D, Castellano D, Simonet AM, Molinilllo JMG. Degradation studies on benzoaxinoids: soil degradation dynamics of (2R)-2-O- $\beta$-D-glucopyranosyl-4-hydroxy-(2H)-1,4-benzoxazin-3(4H)-one (DIBOA-GIC) and its degradation products, phytotoxic allelochemicals from Gramineae. J Agric Food Chem 2005b;53:55461. Available from: https://doi.org/10.1021/jf048702।

Macías M, Ulloa M, Gamboa A, Toscano RA, Mata R. Phytotoxic naphthopyranone derivatives from the croprophilous fungus Guanomyces polythrix. Phytochemistry. 2001;58(5):751-8. Available from: https://doi.org/10.1016/s0031-9422(01)00278-3

Marrone PG. Pesticidal natural products: status and future potential. Pest Manag Sci. 2019;75(9):2325-40. Available from: https://doi.org/10.1002/ps.5433

Martínez-Luis S, Pérez-Vásquez, Mata R. Natural products with calmodulin inhibitor properties. Phytochemistry. 2007;68(14):1882-903. Available from: https://doi.org/10.1016/j.phytochem.2007.02.025

Mata R, Gamboa A, Macias M, Santillan S, Ulloa M, González C. Effect of selected phytotoxins from Guanomyces polythrix on the calmodulin-dependent activity of the enzymes cAMP phophodiestrase and NAD-kinase. J Agric Food Chem. 2003;51(6):4559-62. Available from: https://doi.org/10.1021/jf030115x

May JW, Goss JR, Moncorge JM, Murphy MW. SD 95481 a versatile new herbicide with wide spectrum crop use. In: Proceeding of British Crop Protection Conference; Brighton, England. Alton: British Crop Protection Council; 1985. p. 265-70.

Mitchell JK, Yerkes CN, Racine SR, Lewis EH. The interaction of two potential fungal bioherbicides and a sub-lethal rate of glyphosate for the control of shattercane. Biol Cont. 2008;46(3):391-9. Available from: https://doi.org/10.1016/j.biocontrol.2008.02.009

Morin L. Progress in biological control of weeds with plant pathogens. Annu Rev Phytopath. 2020;58:201-23. Available from: https://doi.org/10.1146/annurev-phyto-010820-012823

Morris MJ. A method for controlling Hakeo sericeo Shrad. Seedlings using the fungus Colletotrichum gleoeoporoides (Penz.) Sacc. Weed Res. 1989;29(6):449-54. Available from: https://doi. org/10.1111/j.1365-3180.1989.tb01317.x

Morris MJ, Wood AR, Breeÿen A. Plant pathogens and biological control of weeds in South Africa: a review of projects and progress during the last decade. Afr Entomol Mem. 1999;1:129-37.

Motlagh MRS. Evaluation of Alternario alternoto causing leaf spot of barnyardgrass grown in rice fields. Afr $J$ Microbiol Res. 2012;6(21):4481-8. Available from: https://doi.org/10.5897/ AJMR11.717
O'Sullivan J, van Acker R, Grohs R, Riddle R. Improved herbicidal efficacy for organically grown vegetables. Org Agric. 2015;5(4):315-22. Available from: https://doi.org/10.1007/s13165-015-0107-5

Owens DK, Bajsa-Hirschel J, Duke So, Carbonari CA, Gomes GLGC, Asolkar R et al. The contribution of romidepsin to the herbicidal activity of Burkholderia rinojensis bioherbicide. $J$ Nat Prod. 2020;83(4):843-51. Available from: https://doi.org/10.1021/acs. jnatprod.9b00405

Peng G, Wolf TM. Herbicide-microbial synergy for improved weed control. Pest Technol. 2011;5(spe 1):18-27.

Phatak SC, Sumner DR, Wells HD, Bell DK, Glaze NC. Biological control of yellow nutsedge with the indigenous rust fungus Puccinio conaliculate. Science. 1983;219(4591):1446-47. Available from: https://doi.org/10.1126/science.219.4591

Portela VO, Moro A, Santana NA, Baldoni DB, Castro IA, Antoniolli Al et al. First report on the production of phytotoxic metabolites by Mycoleptodiscus indicus under optimized conditions of submerged fermentation. Environ Technol. 2020:1-13. Available from: https://doi.org/10.1080/09 593330.2020.1836030

Qu RY, He B, Yang JF, Lin HY, Yang WC, Wu QY et al. Where are the new herbicides? Pest Manag Sci. 2021;77(6):2620-5. Available from: https://doi.org/10.1002/ps.6285

Ridings WH. Biological control of strangler vine in citrus: a researchers view. Weed Sci. 1986;34(Suppl. 1):31-2. Available from: https://doi. org/10.1017/S004317450006834X

Rios MY, Córdova-Albores LC, Ramirez-Cisneros MA, King-Díaz B, Lotina-Hennsen B, Rivera IL et al. Phytotoxic potenetial of Zanthoxylum affine and its major compound linarin as a possible natural herbicide. ACS Omega. 2018;3(11):11779-87. Available from: https://doi.org/10.1021/ acsomega.8b02020

Ruiu L. Microbial biopesticides in agroecosystems. Agronomy. 2018;8(110):1-12. Available from: https://doi.org/10.3390/agronomy8110235

Sands DC, Miller RV. Altering the host range of mycoherbicides by genetic manipulation. In: Duke SO, Menn JJ, Plimmer JR, editors. Pest control with enhanced environmental safety. Washington: American Chemical Society; 1990. p. 101-9

Scheible WR, Fry B, Kochevenko A, Schindelasch D, Zimmerli L, Sommerville $S$ et al. An Arabidopsis mutant resistant to thaxtomin A, a cellulose synthesis inhibitor from Streptomyces species. Plant Cell. 2003;15(8):1781-94. Available from: https://doi.org/10.1105/ tpc.013342

Shrestha A, Moretti M, Mourad N. Evaluation of thermal implements and organic herbicide for weed control in a nonbearing almond (Prunus dulcis) orchard. Weed Technol. 2012;26(1):110-6. Available from: https://doi.org/10.1614/WT-D-11-00083.1

Siehl DL, Subramanian MV, Walters EW, Lee S-F, Anderson RJ, Toschi AG. Adenylosuccinate synthetase: site of action of hydantocydin, a microbial phytotoxin. Plant Physiol. 1996;110(3):753-8. Available from: https://doi.org/10.1104/pp.110.3.753 
Sokornova SV, Berestetskiy AO. [Liquid fermentation of Stogonosporo cirsii C-163, a potential mycoherbicide for Circium arvense (L.) Scop] Agric Biol. 2018;53(5):1054-61. Russian. Available from: https://doi. org/10.15389/agrobiology.2018.5.1054eng

Sparks TC, Duke SO. Structure simplification of natural products as a lead generation approach in crop production compound discovery. $J$ Agric Food Chem. 2021;69(30):8324-46. Available from: https://doi. org/10.1021/acs.jafc.1c02616

Sparks TC, Hahn DR, Garizi NV. Natural products, their derivatives, mimics and synthetic equivalents: role in agrochemical discovery. Pest Manag Sci. 2017;73(4):700-15. Available from: https://doi. org/10.1002/ps.4458

Taban A, Saharkhiz MJ, Kavoosi G. Development of pre-emergence herbicide based on Arabic gum-gelatin, apple pectin and savory essential oil nano-particles: a potential green alternative to metribuzin. Int J Biol Macromol. 2021;167:756-65. Available from: https://doi.org/10.1016/j. ijbiomac.2020.12.007

Tachibanca K. [Bialaphos, a natural herbicide]. Meiji Seika Kenkyu Nenpo. 2003;42:44-57. Japanese.

Tada T, Kanzaki H, Norita E, Uchiyama H, Nakamura I. Decreased symptoms of rice blast disease on leaves of bar-expressing transgenic rice plants following treatment with bialaphos. Mol Plant Microbe Interact. 1996;9(8):762-4.

Takano HK, Dayan FE. Glufosinate-ammonium: a review of the current state of knowledge. Pest Manag Sci. 2020;76(12):3911-25. Available from: https://doi.org/10.1002/ps.5965

Tegg RS, Shabala SN, Cuin TA, Davies NW, Wilson CR. Enhanced resistance to the cellulose biosynthetic inhibitors thaxtomin A and isoxaben in Arabidopsis thaliono mutants, also provides specific co-resistance to the auxin transport inhibitor, 1-NPA. BMC Plant Biol. 2013;13:1-10. Available from: https://doi.org/10.1186/14712229-13-76

Teshler MP, Ash GJ, Zolotarov Y, Watson AK. Increased shelf life of a bioherbicide through combining modified atmosphere packaging and low temperatures. Biocon Sci Technol. 2007;17(4):387-400. Available from: https://doi.org/10.1080/09583150701213695

Thakur N, Kaur S, Tomar P, Thakur S, Yadav AN. Microbial biopesticides: current status and advancement for sustainable agricultural and environment. In: Rastegari AA, Yadav AN, Yadav N, editors. New and future developments in microbial biotechnology and bioengineering. Amsterdam: Elsevier; 2020. p. 243-82.

Vaughn SF, Spencer GF. Volatile monoterpenes as potential parent structures for new herbicides. Weed Sci. 1993;41(1):114-9. Available from: https://doi.org/10.1017/S0043174500057672

Venturelli S, Belz RG, Kämper A, Berger A, von Horn K, Wegner A et al. Plants release precursors of histone deacetylase inhibitors to suppress growth of competitors. Plant Cell. 2015;27(11):3175-89. Available from: https://doi.org/10.1105/tpc.15.00585

Vieira BS, Dias LVSA, Langoni VD, Lopes EA. Liquid fermentation of Colletotrichum truncatum UFU 280, a potential mycoherbicide for beggartick. Aust Plant Pathol. 2018;47:277-83. Available from: https://doi.org/10.1007/s13313-018-0555-y

Wang $Y$, Browning $M$, Ruemmele BA, Chandlee JM, Kausch AP Jackson N. Glufosinate reduces fungal diseases in transgenic glufosinate-resistant bentgrasses (Agrostis spp.). Weed Sci. 2003; 51(1):130-7. Available from: https://doi.org/10.1614/0043-1745(2003)0 51[0130:GRFDIT]2.0.CO;2

Watson AK. Microbial herbicides. In: Korres NE, Burgos NR, Duke SO, editors. Weed control: sustainability, hazards and risks in cropping systems worldwide. Boca Raton: CRC; 2018. p. 133-52.

Weaver MA, Lyn ME, Boyette CD, Hoagland RE. Bioherbicides for weed control In: Upadhyaya MK, Blackshaw RE, editors. Non-chemical weed management. Wallingford: CAB International; 2007. p. 93-110.

Westwood JH, Charudattan R, Duke SO, Fennimore SA, Marrone P, Slaughter DC et al. Weed control in 2050: perspectives on the future of weed science. Weed Sci. 2018;66(3):275-85. Available from: https:// doi.org/10.1017/wsc.2017.78

Wild A, Ziegler $C$. The effect of bialaphos on ammonium-assimilation and photosynthesis I: effect on the enzymes of ammonium-assimilation. Z Naturforsch. 1988;44(1-2),97-102. Available from: https://doi. org/10.1515/znc-1989-1-217

Wolfe JC, Neal JC, Harlow CD. Selective broadleaf weed control in turfgrass with the bioherbicides Phomo mocrostomo and thaxtomin A. Weed Technol. 2016a;30(3):688-700. Available from: https://doi.org/10.1614/WT-D-15-00159.1

Wolfe JC. Neal JC, Harlow CD, Gannon TW. Efficacy of the bioherbicide thaxtomin A on smooth crabgrass and annual bluegrass and safety in cool-season turfgrasses. Weed Technol. 2016b;30(3):733-42. Available from: https://doi.org/10.1614/WT-D-15-00158.1

Yan Y, Liu Q, Zang X, Yuan S, Bat-Erdene U, Nguyen C et al. Resistance-gene-directed discovery of a natura-product herbicide with a new mode of action. Nature. 2018;559:415-8. Available from: https://doi.org/10.1038/s41586-018-0319-4

Young SL. Natural product herbicides for control of annual vegetation along roadsides. Weed Technol. 2004:18(3):580-7. Available from: https://doi.org/10.1614/WT-03-094R3

Yue S, Kong Y, Shen Q, Cui Q, Chen Y., Zhao M. Assessing the efficacy-risk of the widely used chiral glufosinate: switch from the racemate to the single enantiomer? Environ Sci Technol Lett. 2020;7(3):143-8. Available from: https://doi.org/10.1021/acs.estlett.9b00789

Zhou B, Wang H, Meng B, Wei R, Wang L, An C et al. An evaluation of tenuazonic acid, a potential biobased herbicide in cotton. Pest Manag Sci. 2019;75(9):2482-9. Available from: https://doi.org/10.1002/ps.5402

Zidack N, Quimby Jr PC. Formulation of bacteria for biological weed control using the Stabileze method. Biocon Sci Technol. 2002;12(1):6774. Available from: https://doi.org/10.1080/09583150120093112

Zvinavashe T, Mardad I, Mhada M, Kouisni L, Marelli B. Engineering the plant microenvironment to facilitate plant-growth-promoting microbe association. J Agric Food Chem. 2021. Available from: https://doi.org/10.1021/acs.jafc.1c0013 